\title{
EXAMINATION OF MARKET STRUCTURE IN SELECTED LIVESTOCK AGRI-FOOD CHAINS IN THE CZECH REPUBLIC
}

\author{
L. Rumánková
}

Received: August 10, 2012

\begin{abstract}
RUMÁNKOVÁ, L.: Examination of market structure in selected livestock agri-food chains in the Czech Republic. Acta univ. agric. et silvic. Mendel. Brun., 2012, LX, No. 7, pp. 243-258

This paper deals with a description of the most important livestock agri-food chains in the Czech Republic and an evaluation of their vertical price transmission. The paper examines the pork, beef, poultry, and milk agri-food chains generally from May 2004 to June 2011. The time series of selected variables contain biweekly, monthly or annual data and, according to data availability, contain a different number of observations within the selected period. The first part of the paper is focused on a descriptive analysis of the selected agri-food chains. Long-term developments and short-term fluctuations in production, supply and consumption, being the main factors which influence price level, are examined in particular. The second part of the paper is focused on vertical price transmission in the selected agri-food chains; specifically, the relationship between farm-gate price and wholesale price is examined and explained. For this purpose multivariate time series analysis is employed, namely the VAR and VECM models. Based on the empirical analysis, it could be concluded that the assumed long-term relationship was not confirmed for all analyzed agri-food chains. On the other hand, imperfect competition was confirmed; even its form may differ among the analyzed agri-food chains. However, generally speaking, one could say that wholesalers have a stronger position than farmers.
\end{abstract}

time series, VAR, VECM, vertical price transmission, livestock, agri-food chain

Livestock production plays an important role in the national economy as well as everyday life of the Czech people. The production itself is important for self-sufficiency and stability; the relationship between production, total supply, and consumption is important in connection with foreign trade as well as national and EU agrarian policy. In 2009 the consumption of pork reached a value of $40.9 \mathrm{~kg} /$ year/capita, consumption of beef $9.4 \mathrm{~kg} /$ year/capita, consumption of poultry $24.8 \mathrm{~kg} /$ year/capita, and consumption of milk 58 l/year/capital. Meat, milk and milk products are important components of nourishment. Thus, an appropriate level for their production is crucial. The amount of production, as well as its stability and competitiveness, can be considered one of the most important factors for each agri-food chain. Competitiveness in connection with foreign trade and total supply plays an important role for consumers - the price level of essential commodities (necessary goods) plays a key role when they are shopping. Prices are influenced by many factors. In this paper the relationship between farm-gate price and wholesale price in selected agri-food chains is analyzed as an important topic relating to production, and as the first stage in determining the consumer price of a commodity.

Analyses of agri-food markets and price transmission can be found in several research

1 Statistical Yearbook of the Czech Republic 2011. Czech Statistical Office, Prague 2011. 
papers and studies. Czech livestock agri-food chains have been analyzed in Malý (2009), Čechura et al. (2010), Mach et al. (2010), Maier, Pánková (2010), Malý et al. (2011), Šobrová et al. (2011) and Palát et al. (2012), among others. Malý (2009) estimated a partial equilibrium model for the poultry market and, using an autoregressive distributed lag model, determined the long-term tendencies of the farm-gate price, wholesale price, and consumer price of poultry. Čechura et al. (2010) described the development of the main factors of selected Czech agri-food chains and estimated production functions in order to explain the influence of the main determinants on the production of selected commodities. Mach et al. (2010) defined the main production factors and examined their influence on the production of beef based on an estimated production function, while Maier, Pánková (2010) defined the main production factors and employed an estimated production function to examine the influence of these factors on the production of chicken. Malý et al. (2011) defined the main production factors and examined their influence on the production of pork using an estimated production function. Šobrová et al. (2011) estimated a partial equilibrium model describing the main determinants in the production of poultry, as well as its foreign trade and basic consumption tendencies. Palát et al. (2012) evaluated the development of beef meat consumption in the Czech Republic and identified the main factors influencing the consumption.

Foreign livestock agri-food chains and the relationship between farmers and wholesalers/ retailers were described in Miele (1999), Chaddad, Rodrigues-Alcalá (2010), Hartmann (2010), and Leat et al. (2010), among others. Miele (1999) focused on consumption patterns and the relations among individual participants in the agri-food chain. The author showed how strategies of selling food and shopping for lifestyle reasons coalesce with particular forms of production. Chaddad, Rodrigues-Alcalá (2010) described interorganizational relationships in agri-food systems at the vertical, horizontal, and cross-industrial levels. Hartmann (2010) focused on the concept of social structure in agri-food chains and behavioral economics, especially fairness and reciprocity in spot interactions. The author considered that, due to social relations and behavioral rules, economic behavior may deviate from the outcome assumed in neoclassical theory. Leat et al. (2010) described the relationships among individual participants in agri-food chains in selected European countries. The authors concluded that the dynamic nature of the agri-food chain market environment, and the generally low levels of information sharing within agri-food chains, acts to hinder the development of trusting relationships amongst participants.

Vertical price transmission in Czech livestock agri-food chains was examined in Lechanová (2006), Čechura, Šobrová (2008), and Čechura, Šobrová (2009), among others. Lechanová (2006) examined supply and demand shocks and proved the asymmetry of vertical price transmission in the poultry, pork and beef agri-food chains. Čechura, Šobrová (2008) confirmed the simultaneous relationship between the farm-gate price and wholesale price of pork. Moreover, with the help of co-integration analysis and VECM, it was shown that the pork market has an oligopsonic market structure. Based on estimated VECMs, Čechura, Šobrová (2009) showed differences in price transmission between farm-gate price and wholesale price in individual regions of the Czech Republic. Moreover, the analysis shows that processing companies may abuse their market power in relation to farmers. The authors also detected significant interconnections between regional markets at the farmer as well as producer level.

Vertical price transmission in foreign livestock agri-food chains was examined in Bojnec (2002), Lloyd et al. (2004), Bakucs, Fertö (2005), Vavra, Goodwin (2005), and Jensen, Møller (2007), among others. Bojnec (2002) proved the existence of longterm relationships in the Slovenian pork and beef agri-food chains using co-integration analysis and VECM. Lloyd et al. (2004) showed that the beef agrifood chain in Great Britain has an oligopolistic market structure. Moreover, the influence of substitutional commodities on price transmission analysis in the analyzed sector is mentioned. Bakucs, Fertö (2005) proved the exogeneous character of wholesale price in relation to farmgate price in the Hungarian pork agri-food chain, based on co-integration analysis and VECM. Vavra, Goodwin (2005) proved the asymmetry of vertical price transmission in selected US livestock agri-food chains based on co-integration analysis, VECM and Threshold VECM. Jensen, Møller (2007) employed univariate time series analysis and co-integration analysis to examine the asymmetry of vertical price transmission in selected Danish agri-food chains. The analysis proved the existence of the asymmetry, especially over the short term and at the level of consumer prices.

\section{MATERIALS AND METHODS}

The aim of this paper is to examine the market structure of selected livestock agri-food chains in the Czech Republic, and more specifically to describe the main factors in the selected livestock agrifood chains and evaluate their price transmission based on the time series of farm-gate price and wholesale price. The paper is focused on the agrifood chains of pork, beef, poultry and milk. First, the main characteristics of the selected agri-food chains are provided, and the long-term tendencies of selected indicators are shown. Then, vertical price transmission in the selected chains is examined and evaluated.

To fulfill the aim of the paper, the following hypotheses are defined: 
H1: The time series of farm-gate prices and wholesale prices in the selected agri-food chains are non-stationary.

H2: It can be assumed that there is a long-term relationship between farm-gate price and wholesale price in the selected agri-food chains.

H3: It can be assumed that all the analyzed agrifood chains are demand-driven, which means that wholesalers have a stronger position than farmers.

If the first two hypotheses $(H 1, H 2)$ are accepted, the Vector Error Correction Model (VECM) can be employed as a suitable tool for analyzing vertical price transmission.

The aim of this paper will be fulfilled based on the following methods:

1. The first part of the paper, which is focused on descriptive analysis of the main factors/indicators of the selected agri-food markets, is based on the long-term tendencies of the selected indicators (production, supply and consumption) and their short-term fluctuations. These factors can be considered the main factors in the agri-food chain, and their development can also explain the movements and development of farm-gate price as well as wholesale price in individual markets (the main factors analyzed in this paper).

2. The second part of the paper, which is focused on vertical price transmission in the selected agri-food chains, consists of two parts. First, the main properties of the selected time series are shown, and then price transmission is analyzed in the following steps:

i) the main properties of the time series of farmgate price and wholesale price are examined based on the primary statistical characteristics (mean, standard error and coefficient of variation) as well as the Autocorrelation function (ACF) and Partial autocorrelation function (PACF);

ii) the maximal lag of the selected time series is determined based on the Akaike information criterion (AIC);

iii) the stationarity of the selected time series is examined using the Augmented DickeyFuller test (ADF);

iv) the presence of a long-term relationship is analyzed based on co-integration analysis;

v) the relationship between farm-gate price and wholesale price is described using the Vector autoregressive model (VAR) or Vector error correction model (VECM);
The VAR model is a suitable tool for analyzing the short-term relationship between stationary time series, whereas the VECM is suitable for analyzing the long-term relationship between non-stationary time series. VECM can be estimated in the following form:

$$
\Delta X_{t}=\eta+\Pi X_{t-1}+\sum_{s=1}^{p} C_{s} \Delta X_{t-s}+U_{t},
$$

where $C_{s}=0$ for $s>p, X_{t}$ is a $\mathrm{kx} 1$ vector of variables which are supposed to be integrated of order 1 , (I(I)), $\mathrm{u}_{1}, \ldots, \mathrm{u}_{\mathrm{t}}$ are nid $(0, \Sigma)$ and is a matrix of the long-term relationship ${ }^{2}$. The VAR model can be estimated in the following form:

$$
\Delta X_{t}=\eta+\sum_{s=1}^{p} C_{s} \Delta X_{t-s}+U_{t}
$$

where for $C_{s}=0$ for $s>p, X_{t}$ is a $\mathrm{kx} 1$ vector of variables which are supposed to be integrated of order $1,(\mathrm{I}(0))$, $\mathrm{u}_{1}, \ldots, \mathrm{u}_{\mathrm{t}}$ are nid $(0, \Sigma)$;

vi) (vi) the long-term relationship is examined based on matrix and the value of price transmission elasticity; ${ }^{3}$

vii)(vii) the properties of the estimated model are examined using residual analysis and additional tests, i.e., the test of weak exogeneity, exclusion, autocorrelations of residuals, etc.

The time series of supply, demand and consumption, as well as the time series of farmgate price and wholesale price in selected agri-food chains, were provided by the Ministry of Agriculture and the State Agricultural and Interventional Fund. The time series of supply, demand and consumption contain annual data from 1998 to 2009. The time series of the farm-gate price and wholesale price of pork and beef contain bi-weekly data from the period from May 2004 to June 2011. The time series of the farm-gate price and wholesale price of poultry contain monthly data for the period from May 2004 to April 2011. The time series of the farm-gate price and wholesale price of milk contain monthly data for the period from July 2007 to May 2011.

Price transmission models were estimated using the Ordinary Least Squares Method (OLSM) in the econometric software RATS 6.35 and CATS 2.0.

2 Within the matrix $\Pi$, vectors $\alpha$ and $\beta$ are quantified. Vector $\alpha$ is important for explaining how the system reacts to reach equilibrium after a unitary shock; moreover, it can be used to verify a simultaneous relationship among the variables. Vector $\beta$ contains the value of price transmission elasticity that can be used to determine the nature of the market structure of the analyzed agri-food chain.

3 This step is included just in case the VECM is inappropriate to the relationship between the time series of farm-gate price and wholesale price. Price transmission elasticity shows a percentage change in the explained price, caused by a $1 \%$ increase in the explanatory price level. 


\section{RESULTS}

\section{Descriptive analysis}

The descriptive analysis is focused on the development of production, supply and domestic consumption of pork, beef, poultry and milk in the Czech Republic. The time series contain monthly data for the period from 1998 to 2009. This analysis is important for detecting the main tendencies within individual agri-food chains, and for understanding the influence of the main factors on the level and development of prices.

\section{Pork}

Fig. 1 shows the development of the production, supply and consumption of pork in the Czech Republic from 1998 to 2009. The development of supply and consumption is almost the same in the analyzed period; in fact, the level of supply is even higher than the level of consumption. However, both indicators seem to be almost stable since the year 2000. Up until then, all examined indicators decreased. The long-term trend in the production of pork does not correspond to the development of supply and consumption. It is obvious that production rapidly decreased in the examined period. The production of pork in the year 2009 only reached $55 \%$ of the production level in the year 1998. This extreme decline was caused by conditions in the Czech Republic, especially after EU accession. Czech farmers were not able to compete with foreign farmers and their cheap imports. Due to the constant level of pork consumption, decreasing production must be (and is) substituted by imports. When domestic production is insufficient, imports play a key role in the pork agri-food chain.

\section{Beef}

Fig. 2 shows the development of the production, supply and consumption of beef in the Czech Republic for the period from 1998 to 2009. The longterm tendency of all indicators is a slight decrease over the analyzed period. Only in the case of supply, an increase can be seen in the last two periods. The long-term trend of all indicators is decreasing, especially up until the year 2004; after that year, the indicators show a stable tendency (except for supply, as mentioned above). The development of consumption was also influenced significantly by the occurrence of $\mathrm{BSE}^{4}$. The production of beef was also influenced by this event; however, the

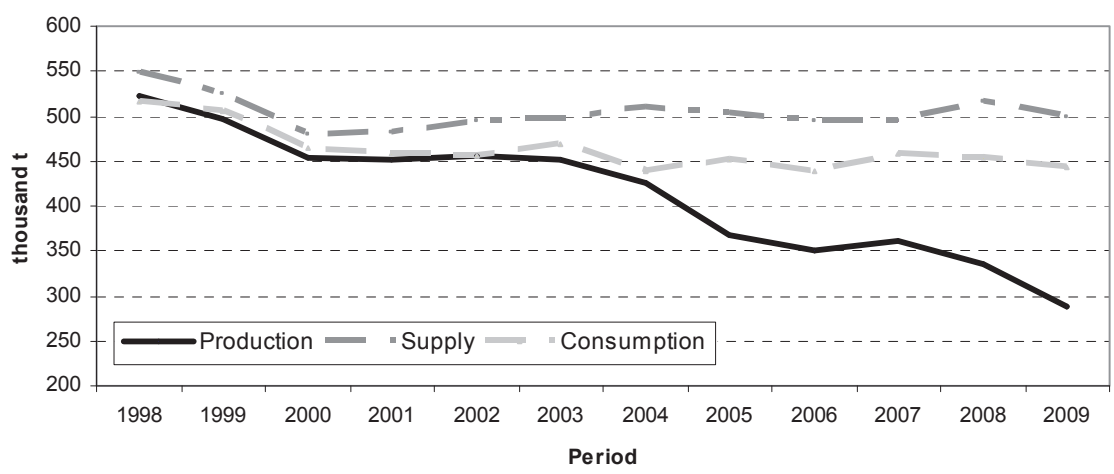

1: Pork

Source: author's processing

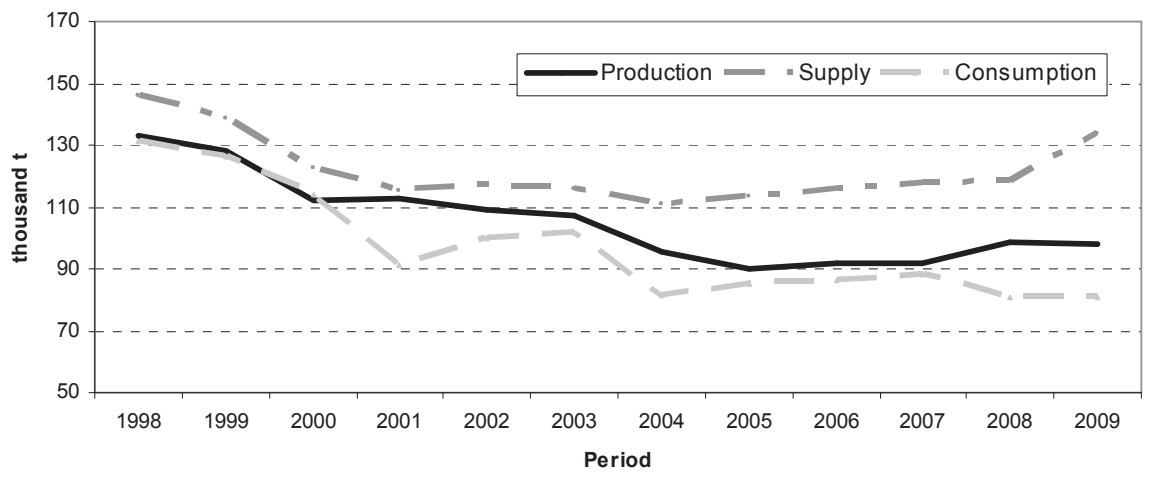

2: Beef

Source: author's processing 
consumption of beef was influenced even more by this potential threat. Moreover, the economic crisis also influenced the selected indicators, as can be seen in the graph. The graph also shows that domestic production satisfies consumption in all periods; however, no large difference between production and consumption was detected. Due to the decreasing (or stable) amount of beef production, the increasing quantity of beef supply is achieved through imports.

\section{Poultry}

Fig. 3 shows the development of the production, supply and consumption of poultry in the Czech Republic from 1998 to 2009. All the curves show a similar development in the analyzed period the same peaks, decreases and increases. However, the development of production differs from the development of supply and consumption after the year 2005. Up until the year 2005, the longterm tendency of all indicators was increasing, and some short-term decreases could even be seen. However, since the year 2005 all these indicators have decreased. The consumption and supply of poultry decreased only in the first two years, and then it seemed to stabilize. On the other hand, the decreasing tendency of production is obvious. Production in the year 2009 decreased by $16 \%$ compared to the level in 2005. This could be considered a reaction to the EU accession and $\mathrm{CAP}^{5}$ employed in the Czech Republic. Due to decreasing production, the constant amount of consumption in the recent period must be (and is) met by increasing imports (cheap imports, which also influences the extent of poultry production in the Czech Republic).

\section{Milk}

Fig. 4 shows the development of the production, supply and consumption of milk in the Czech Republic from 1998 to 2009. Based on the graph, it is obvious that the level of production is stable. On the other hand, there is clearly an increasing tendency in the supply of milk. The amount of supply mirrors the development of consumption, even though the level of consumption is much lower than the total supply. Moreover, the graph shows an extreme surplus of supply over domestic demand. However, this can be considered a long-term condition, which was not affected by either the EU accession or the economic crisis (even though the EU accession and economic crisis certainly affected the price level of milk and the situation of Czech dairy farmers).

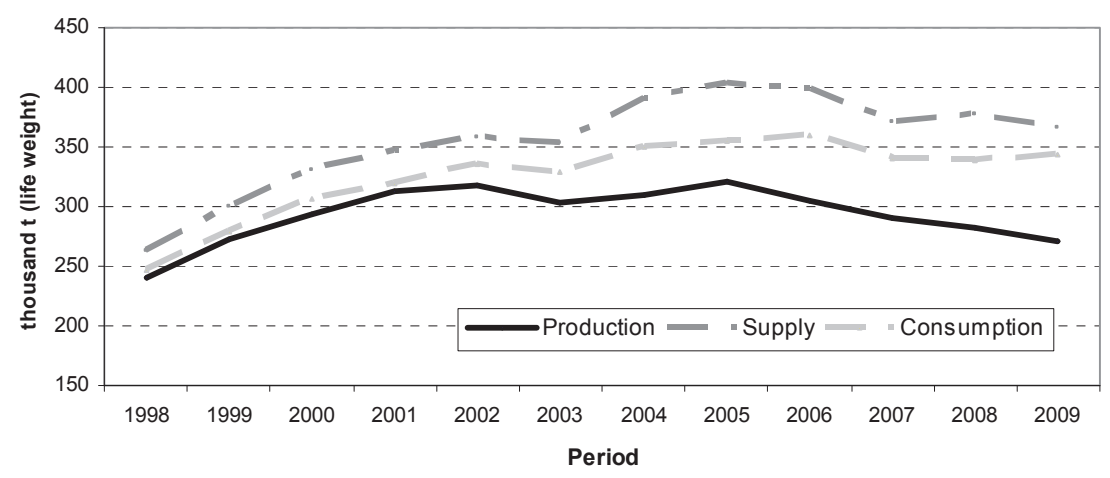

3: Poultry

Source: author's processing

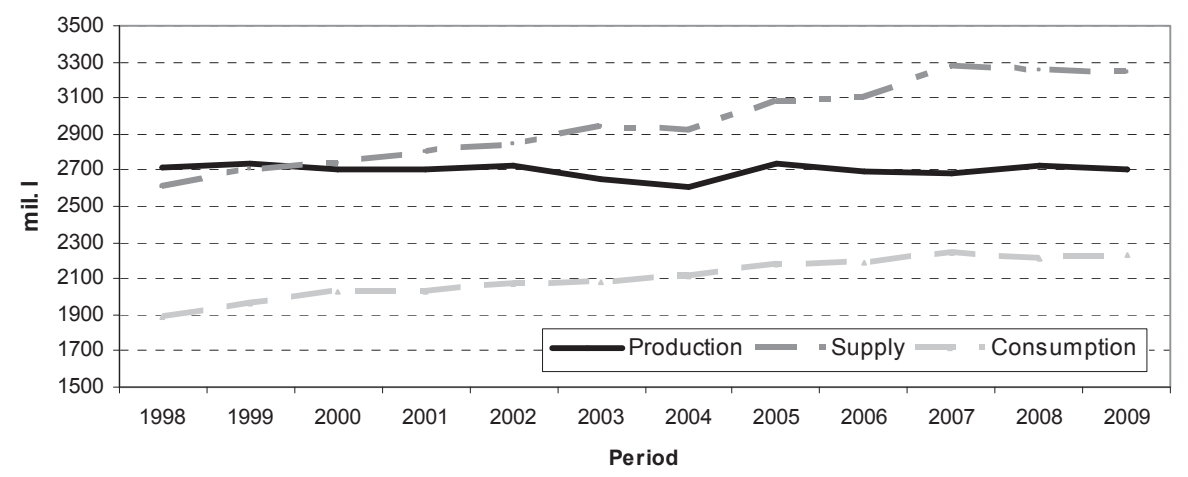

4: Milk

Source: author's processing 


\section{Price transmission analysis}

The price transmission analysis is focused on the relationship between farm-gate price and wholesale price in the agri-food chains of pork, beef, poultry and milk. First of all, the main properties of the selected time series are detected, and then the short-term as well as long-term relationships are examined. The time series of farm-gate price and wholesale price contain monthly or bi-weekly data for the selected period.

\section{Pork agri-food chain}

The time series of the farm-gate price and wholesale price of pork contain bi-weekly data for the period from May 2004 to June 2011. The time series contain 172 observations. The basic statistical characteristics show that the average value of farmgate price reaches the value of $39.44 \mathrm{CZK} / \mathrm{kg}$, while the average value of wholesale price reaches 86.31 $\mathrm{CZK} / \mathrm{kg}$. Moreover, the values of the coefficient of variation show that the variation in the farm-gate price of pork (coefficient of variation equals $10.03 \%$ ) is slightly higher than the variation in the wholesale price of pork (coefficient of variation equals 8.35 $\%$ ). The long-term tendency in both cases is slightly decreasing (see Fig. 5). The variation seems to be influenced by a seasonal component of the time series.

Other properties of the selected time series can be seen through the ACF and PACF functions, for example. These functions show that the seasonal component may occur in the time series of farmgate price but not in the time series of the wholesale price of pork (see Figs. 6a, 6b). Due to the nonseasonal character of the wholesale price time series, the seasonal model is not considered in the following analysis.

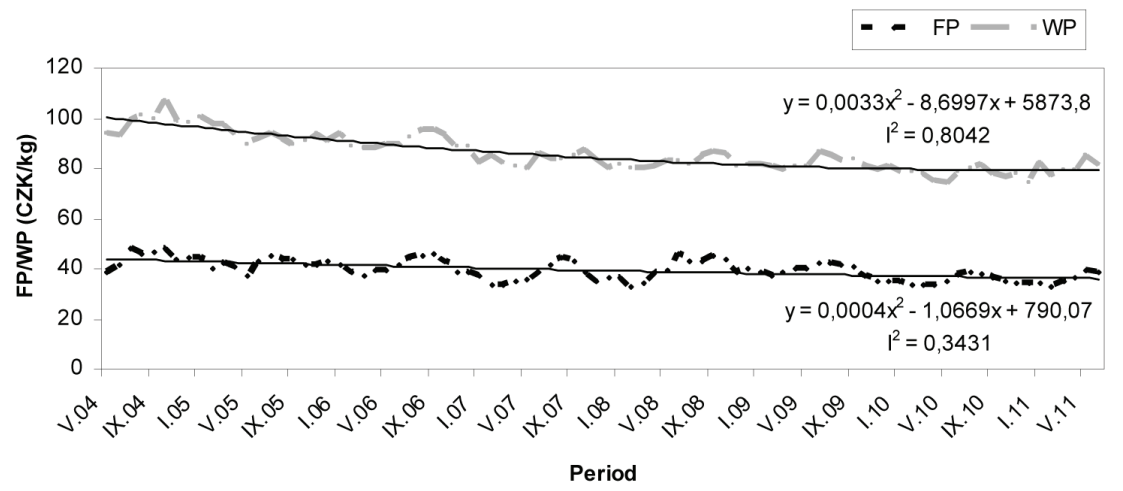

5: FP and WP-pork

Source: author's calculation

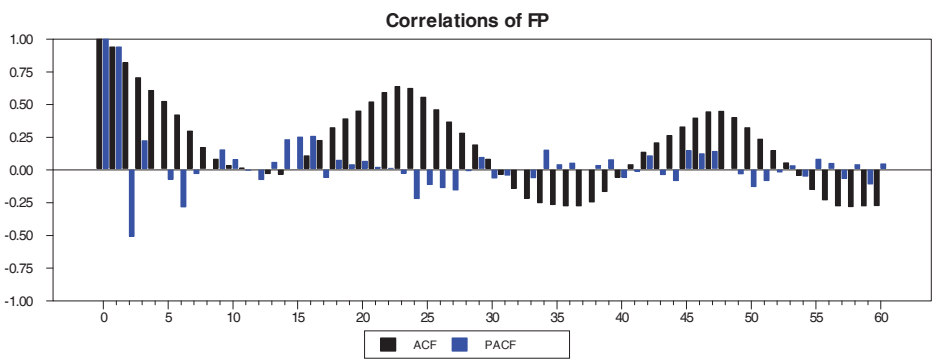

6a: Correlation of FP-pork

Source: author's calculation

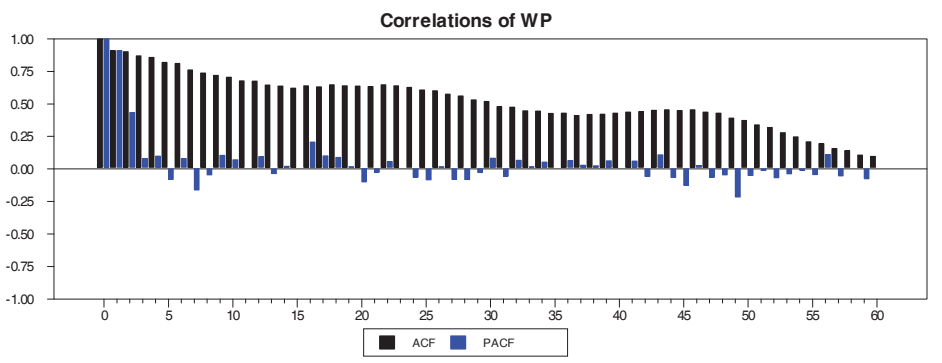

6b: Correlation of WP-pork

Source: author's calculation 
To find the maximal lag, AIC and SBC criteria were employed. Due to the diversity of results, the maximal lag was selected based on a combination of suggestions from these criteria and the author's assumption at the level of 10 periods. The following model therefore specifies a five-month delay as being significant for the relationship between the farm-gate price and wholesale price of pork.

The ADF test was employed to verify whether the time series of farm-gate price and wholesale price

\section{I: VECM model in pork agri-food chain}

\begin{tabular}{|c|c|c|c|c|}
\hline \multicolumn{2}{|c|}{ Beta (transposed) } & \multicolumn{2}{|c|}{ Alpha } & \multirow{2}{*}{$\begin{array}{c}\begin{array}{c}\text { T-values } \\
\text { for Alpha }\end{array} \\
-2.919\end{array}$} \\
\hline $\log \mathrm{FP}$ & $\log W P$ & $\operatorname{logFP}$ & -0.155 & \\
\hline 1.000 & -0.820 & $\log W P$ & 0,109 & 1.947 \\
\hline \multirow{2}{*}{ PI } & & & \multicolumn{2}{|c|}{ T-values for PI } \\
\hline & & & $\log F P$ & $\log W P$ \\
\hline $\log \mathrm{FP}$ & -0.156 & 0.128 & -2.919 & 2.919 \\
\hline $\log W$ & 0.109 & -0.089 & 1.947 & -1.947 \\
\hline
\end{tabular}

Sample: 172; effective sample: 162; degrees of freedom: 141

Source: author's calculation are stationary. The results of the test showed that both time series are non-stationary and integrated of the first order, i.e. I(1). Thus, co-integration analysis can be employed to detect the presence of cointegrating vectors.

Co-integration analysis detected one cointegrating vector in the analyzed relationship at a significance level of $1 \%$; thus, the VECM model can be employed for the following analysis. Due to the presence of a co-integrated vector, the long-run relationship will be analyzed.

Table I contains the parameters of the VECM model, which was estimated to analyze the relationship between the farm-gate price and wholesale price of pork. According to the content of the vector $\beta$, imperfect competition, namely an oligopsonic market structure, can be considered for this agri-food chain (price transmission elasticity reaches a value of 0.820 ). This means that wholesalers have a stronger position than farmers, and that the nature of the chain is demand-driven. In addition, the significance of the parameter $\alpha$ does not confirm that a simultaneous relationship exists between the analyzed prices. Similarly, according to

DLFP
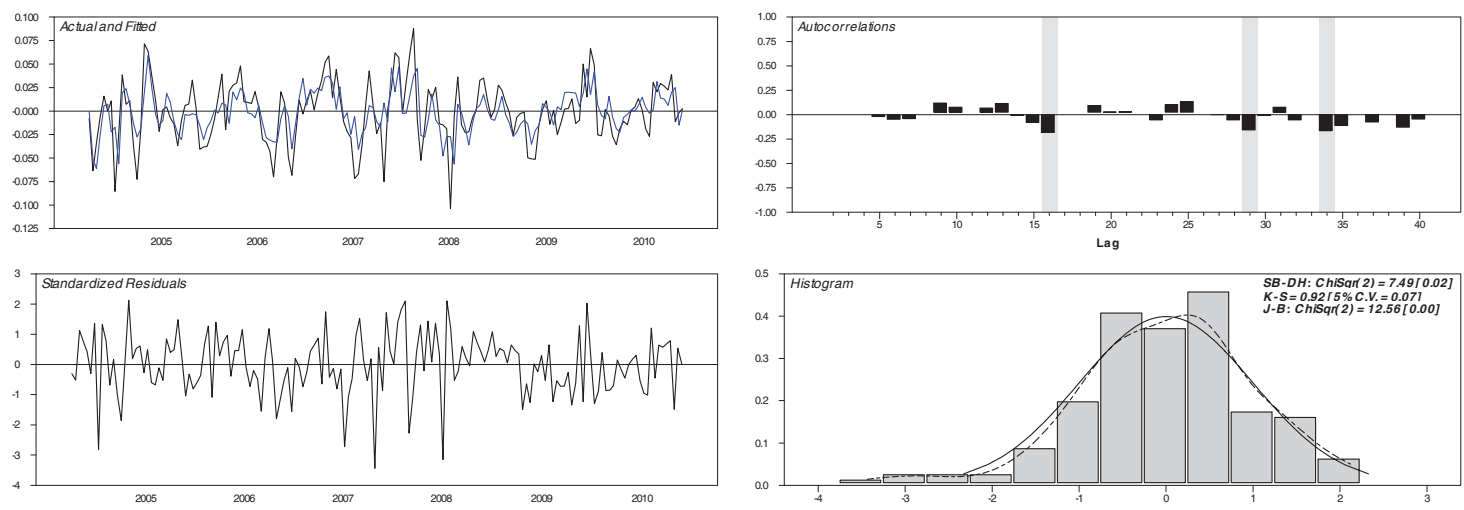

DLWP
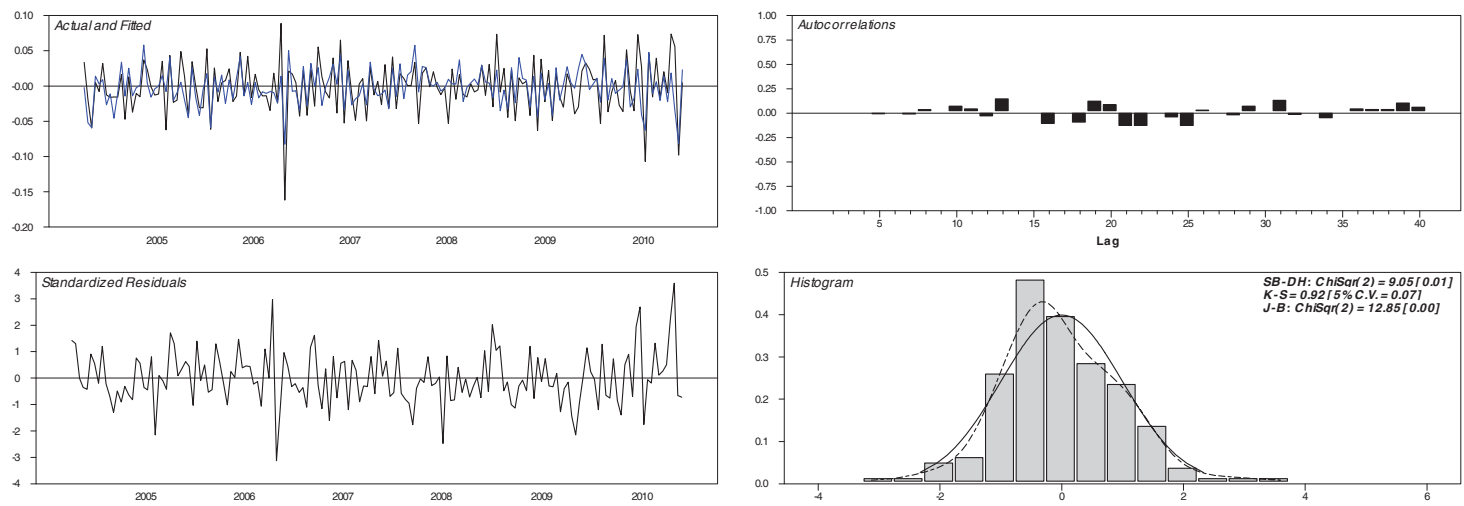

7: Residual analysis of pork VECM

Source: author's calculation 
the test of weak exogeneity, wholesale price seems to be weakly exogenous relative to farm-gate price.

The residual analysis confirms the assumption of the VECM model and provides acceptable results (see Fig. 7). There is not a large difference between the real and fitted values, and the distribution of residuals can be considered normal. On the other hand, an autocorrelation of the first order was detected. This means that the model is not efficient. In any case, the results obtained are valid.

\section{Beef agri-food chain}

The time series of the farm-gate price and wholesale price of beef contain bi-weekly data for the period from May 2004 to June 201l. The time series contain 172 observations. The main statistical characteristics show that the average value of farmgate price equals approximately $57.05 \mathrm{CZK} / \mathrm{kg}$, while the wholesale price equals approximately $123.98 \mathrm{CZK} / \mathrm{kg}$. The variation in the selected time series is not significant (coefficient of variation equals $4.79 \%$ in the case of FP and $3.44 \%$ in the case of WP). The long-term tendency does not show any drastic increase or decrease (see Fig. 8). Moreover, the development of the wholesale price of beef seems to be the same as the development of the farm-gate price of beef.

The basic statistical characteristics of the selected time series are accompanied by the ACF and PACF functions (see Figs. 9a, 9b). These functions show a seasonal fluctuation in farm-gate price. No seasonal component was detected for the wholesale price time series.

The maximal lag was selected with the help of AIC and SBC criteria. Due to the varied results, 12 lags were finally selected as appropriate for the analyzed

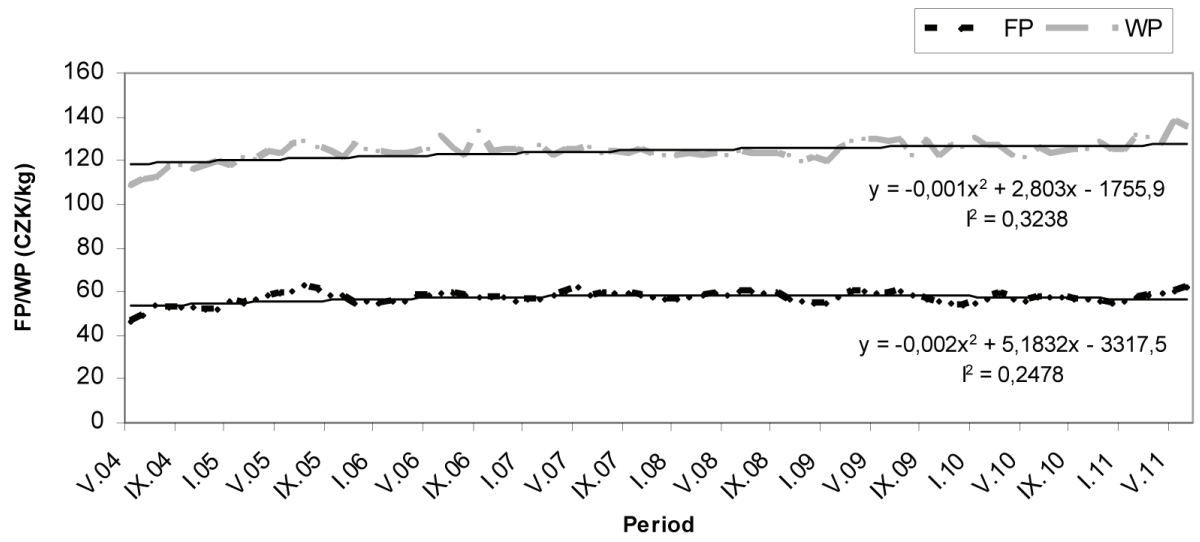

8: FPand WP-beef

Source: author's calculation

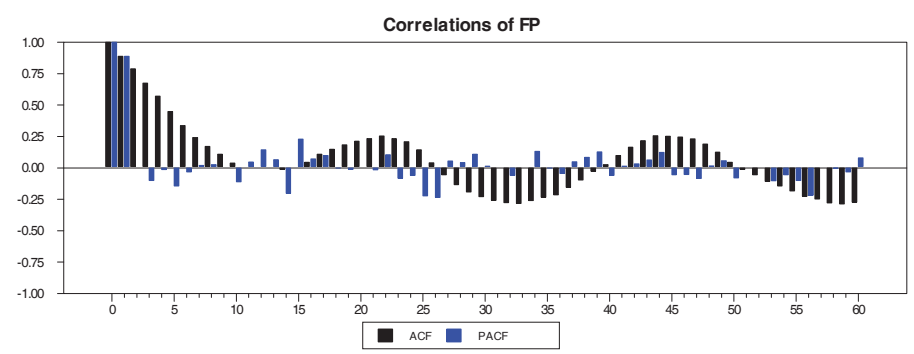

9a: Correlation of FP- beef

Source: author's calculation

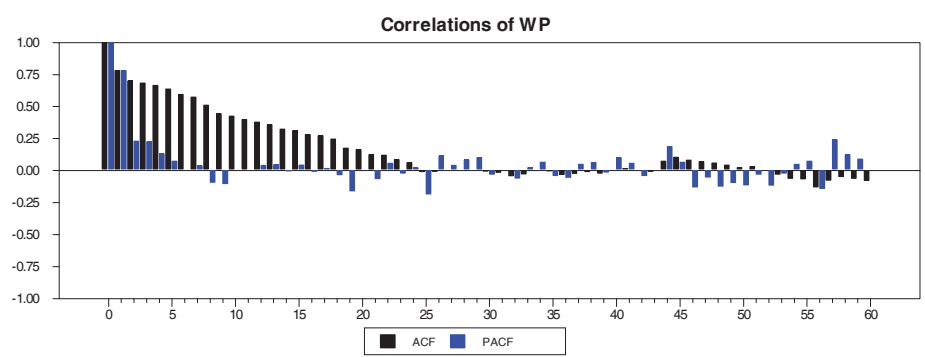

9b: Correlation of WP-beef

Source: author's calculation 
relationship. Thus, a six-month delay is considered significant in the following analysis.

Subsequently, the stationary character of the time series of farm-gate price and wholesale price was examined. The ADF test showed that both time series are non-stationary and integrated of the first order, i.e. I(1).

Co-integration analysis was then employed to detect the presence of a long-term relationship between the farm-gate price and wholesale price of

II: VECM model in beef agri-food chain

\begin{tabular}{|c|c|c|c|c|}
\hline \multicolumn{2}{|c|}{ Beta (transposed) } & \multicolumn{2}{|c|}{ Alpha } & \multirow{2}{*}{$\begin{array}{c}\begin{array}{c}\text { T-values } \\
\text { for Alpha }\end{array} \\
-4.627\end{array}$} \\
\hline $\log \mathrm{FP}$ & $\log W P$ & $\log \mathrm{FP}$ & -0.250 & \\
\hline 1.000 & -0.037 & $\log W P$ & -0.091 & -1.621 \\
\hline \multirow{2}{*}{\multicolumn{2}{|c|}{ PI }} & & \multicolumn{2}{|c|}{ T-values for PI } \\
\hline & & & $\log F P$ & $\log W P$ \\
\hline $\operatorname{logFP}$ & -0.250 & 0.009 & -4.627 & 4.627 \\
\hline $\log W$ & -0.091 & 0.003 & -1.621 & 1.621 \\
\hline
\end{tabular}

Sample: 172; effective sample: 160; degrees of freedom: 135

Source: author's calculation beef. This analysis found one co-integrating vector at a significance level of 5\%, and therefore VECM can be employed for the following analysis.

Due to the seasonal component found in the time series of the farm-gate price of beef, the seasonal VECM was estimated and employed for the price transmission analysis of the beef agri-food chain. However, the results were unsatisfactory, as the residual analysis provided insignificant values and the assumptions of the VECM model were not confirmed. As a result, a VECM with no seasonal component was estimated and examined.

Table II contains the main parameters of the VECM model in the beef agri-food chain in the Czech Republic. According to the vector $\beta$, one could conclude that the position of wholesalers is stronger than the position of beef producers. The value of price transmission elasticity (0.037) shows that the beef agri-food chain can be considered oligopsonic. The parameters $\alpha$, although significant, do not confirm the assumption of a simultaneous relationship among prices. According to these values, the wholesale price seems to be exogenous.

The test of exclusion and the test of weak exogeneity suggest considering the wholesale

\section{DLFP}
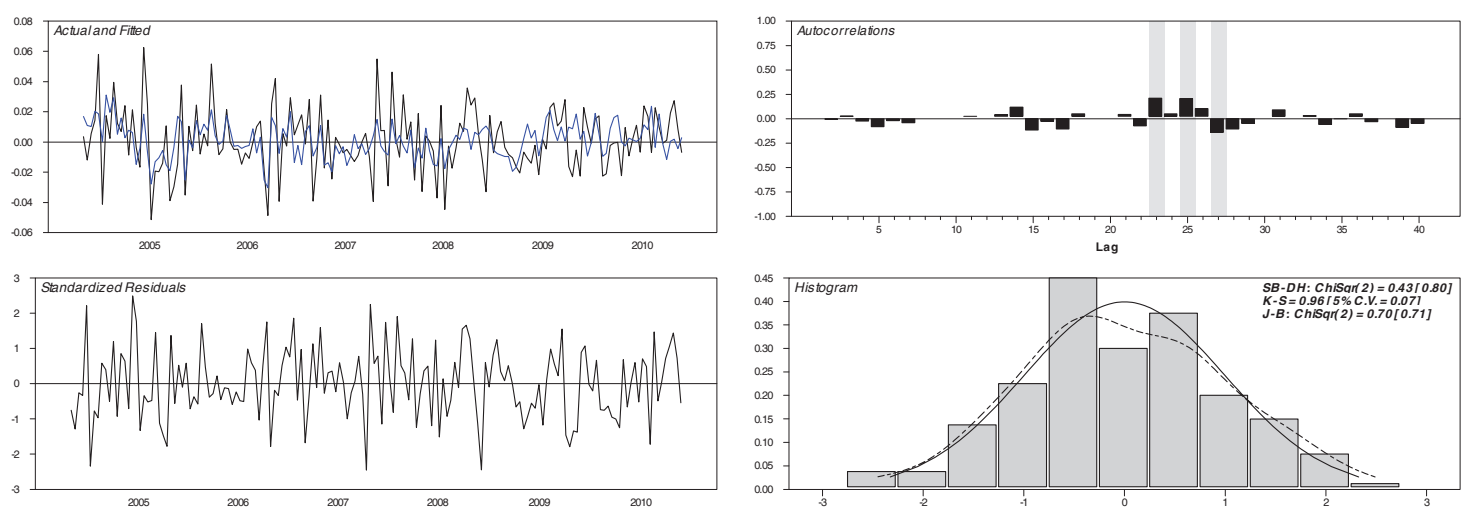

DLWP
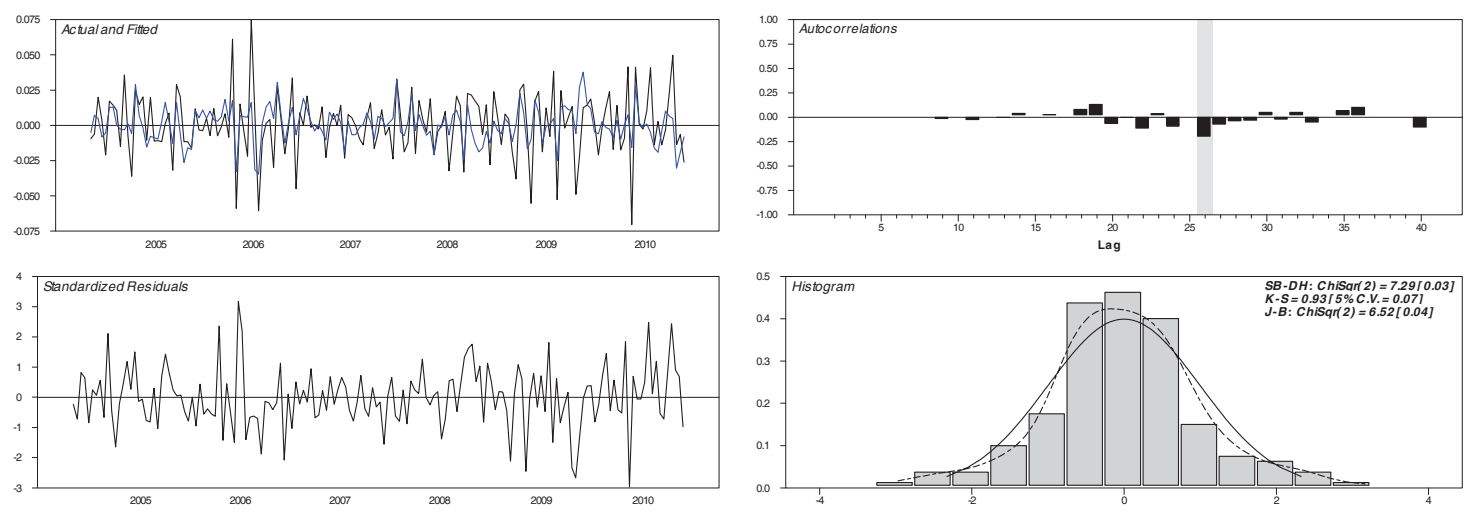

10: Residual analysis of beef VECM

Source: author's calculation 
price to be an exogenous variable. This means that a simultaneous relationship between the farmgate price and wholesale price is inappropriate. A recursive model would probably be more suitable for analyzing price transmission in the beef agrifood chain. In any case, this result highlights the unique position of wholesale price and of wholesalers. Farm-gate price is probably not the main factor affecting the level of wholesale price. The agri-food chain can therefore be considered demand-driven.

Residual analysis provides acceptable results (see Fig. 10). There is not a large difference between the real and fitted values, and the distribution of residuals can be considered normal. However, the model contains an autocorrelation of residuals of the first order. This means that the estimated model is inefficient. In any case, the results obtained can be considered valid.

\section{Poultry agri-food chain}

The time series of the farm-gate price and wholesale price of poultry contain monthly data for the period from May 2004 to April 2011. The time series contain 84 observations. In the analyzed period, the average farm-gate price reaches a value of $21.03 \mathrm{CZK} / \mathrm{kg}$ and the average wholesale price equals $43.27 \mathrm{CZK} / \mathrm{kg}$. According to the values of the coefficient of variation, the wholesale price of poultry fluctuates more than the farm-gate price; however, this fluctuation is not significant the coefficient of variation of FP equals $6.47 \%$ and the coefficient of variation of WP equals $7.87 \%$ ). The long-term tendency of the analyzed time series is slightly increasing, even though the trend functions are not significant (the values of the coefficient of determination are very small). Moreover, the values of wholesale price in particular were significantly influenced by the economic crisis. A significant

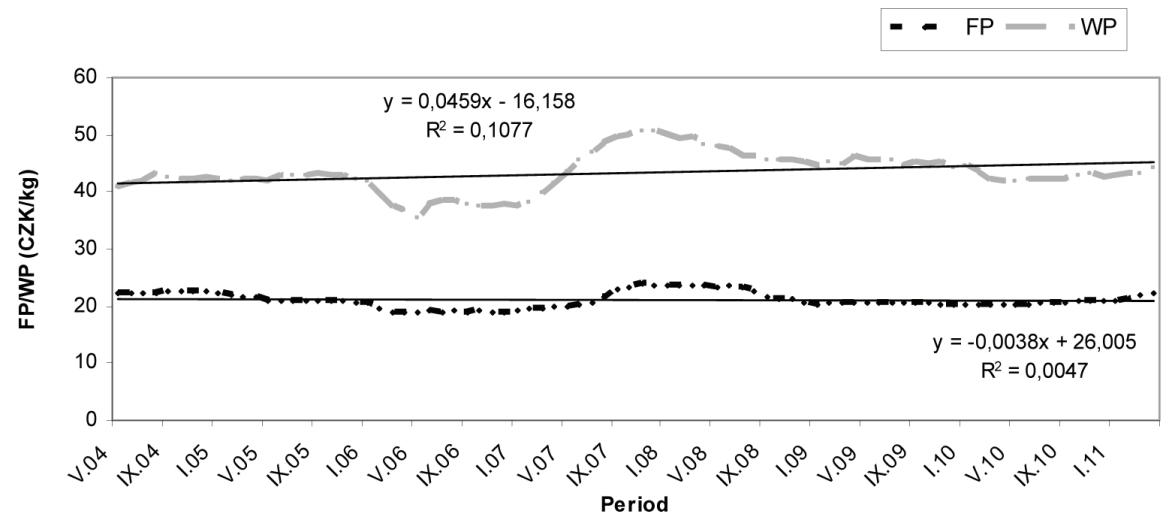

11: FPand WP-poultry

Source: author's calculation

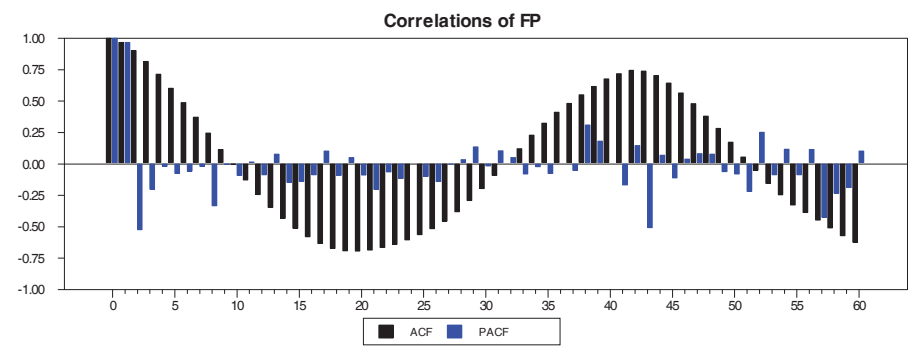

12a: Correlation of FP- poultry

Source: author's calculation

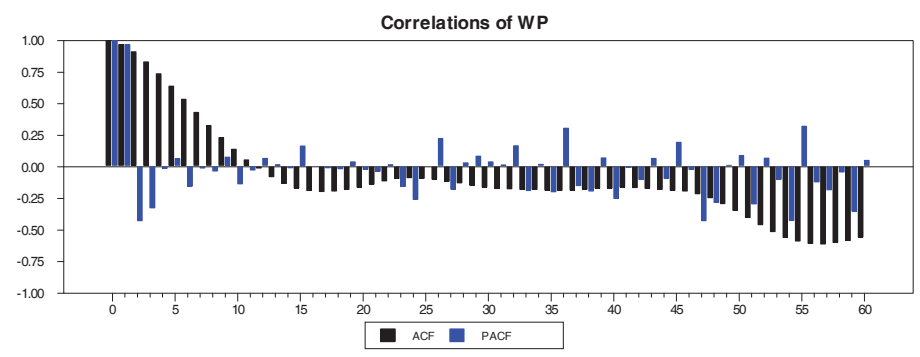

12b: Correlation of WP-poultry

Source: author's calculation 
III: VAR model in poultry agri-food chain

\begin{tabular}{|c|c|c|c|c|c|}
\hline \multicolumn{2}{|c|}{ Dependent variable: dlFP } & \multicolumn{4}{|c|}{ Dependent variable: dlWP } \\
\hline Variable & Parameter & P-value & Variable & Parameter & P-value \\
\hline $\operatorname{dlFP}\{1\}$ & 0.3482 & 0.0062 & $\operatorname{dlFP}\{1\}$ & 0.2016 & 0.2212 \\
\hline $\operatorname{dlFP}\{2\}$ & 0.1110 & 0.4021 & $\operatorname{dlFP}\{2\}$ & 0.0556 & 0.7508 \\
\hline $\operatorname{dlFP}\{3\}$ & -0.0757 & 0.5429 & $\operatorname{dlFP}\{3\}$ & -0.0945 & 0.5662 \\
\hline $\operatorname{dlWP}\{1\}$ & 0.1253 & 0.1814 & $\operatorname{dlWP}\{1\}$ & 0.2486 & 0.0467 \\
\hline $\operatorname{dlWP}\{2\}$ & 0.0869 & 0.3639 & $\operatorname{dlWP}\{2\}$ & 0.2456 & 0.0549 \\
\hline \multirow[t]{2}{*}{$\operatorname{dlWP}\{3\}$} & 0.0449 & 0.6393 & $\operatorname{dlWP}\{3\}$ & -0.0811 & 0.5232 \\
\hline & F-statistics & P-value & & F-statistics & P-value \\
\hline dlFP & 3.6380 & 0.0166 & dlFP & 0.6875 & 0.5625 \\
\hline dlWP & 1.4147 & 0.2453 & dlWP & 3.2564 & 0.0263 \\
\hline
\end{tabular}

Source: author's calculation

increase in wholesale price in the year 2008 can be clearly seen (see Fig. 11).

The seasonal character of farm-gate price and wholesale price was examined based on the ACF and PACF functions. Figs. 12a, 12b only show the presence of seasonal behavior in the time series of farm-gate price. Thus, the different periods of the year seem to be significant for poultry production and its entry into the market.

The AIC and SBC criteria were then employed to find the significant lag of both farm-gate price and wholesale price. The results of the criteria for farmgate price differ (AIC suggests 18 lags whereas SBC suggests just one lag). In the case of wholesale price, the results of both criteria are the same - AIC as well as SBC see no significant lag in this relationship. Due to the varied results and based on the author's assumption, three lags (a three-month delay) were selected as most appropriate for the following analysis.

Subsequently, co-integration analysis was employed to find the long-term relationship between prices in the poultry agri-food chain in the Czech Republic. However, the results do not confirm the assumption. It was not verified that a long-term relationship exists. For this reason, a long memory in the analyzed time series should not be considered. Moreover, it can be concluded that both the farm-gate price and wholesale price of poultry are not influenced by the price level in previous periods; other factors would be more important in this relationship.

Due to the absence of a long-term relationship between farm-gate price and wholesale price, a VAR model was estimated. The parameters of the model and their significance are shown in Table 3. The estimated VAR model shows that the farmgate price lagged one period is the only significant parameter for the dependent variable farm-gate price, at a significance level of $1 \%$. It also shows that wholesale prices lagged two and three periods are the only significant parameters, at a significance level of $5 \%$, which explain the development of wholesale price. In we consider a $1 \%$ significance level, there is no significant lagged variable for wholesale price. These values confirm the result of the AIC and SBC criteria as well as the co-integration analysis. One may conclude that a long-term relationship does not really exist between farm-gate price and wholesale price in the poultry agri-food chain. Moreover, the prices are not set up according to developments in previous periods. This means that the farm-gate price of poultry is not really influenced by the wholesale price, and also that the wholesale price of poultry is not really affected by the farm-gate price. According to the estimated parameters as well as the F-test, both variables seem to be exogenous. If the number of lagged variables were restricted, these results would be confirmed. The model estimated has good properties - at least there is no autocorrelation of the residual, and their distribution can be considered normal.

\section{Milk agri-food chain}

The time series of the farm-gate price and wholesale price of milk contain monthly data from July 2007 to April 2011. Since one value is missing, the time series contain only 45 observations. The data set shows that the average farm-gate price of milk in the analyzed period reaches the value 7.67 $\mathrm{CKZ/l,}$ while the average wholesale price reaches the value of $55.24 \mathrm{CZK} / \mathrm{kg}$. The values of the coefficient of variation show that the fluctuation in time series of wholesale price is higher than the fluctuation in farm-gate price (the coefficient of variation of FP equals $15.71 \%$, while the coefficient of variation of WP equals $20.77 \%)$. The long-term tendencies of both the farm-gate price and wholesale price time series can be described using a polynomial function of the second order (see Fig. 13). In any case, the development of the analyzed time series shows a different pattern. Due to a greater fluctuation in the wholesale price of milk, the changes in the analyzed period are more obvious than in the case of farmgate price. The time series shows the decreasing tendency of the wholesale price of milk from 2007 


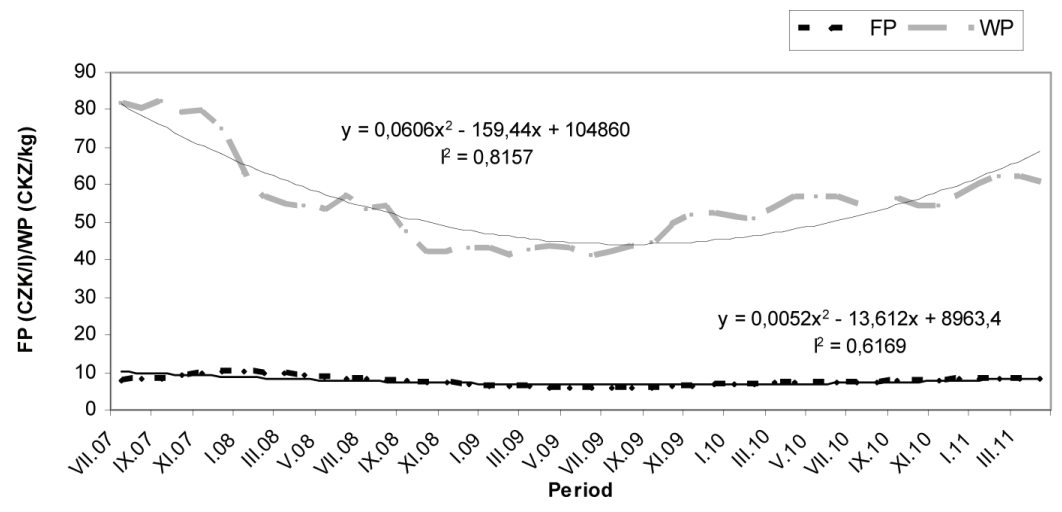

13: FP and WP-milk

Source: author's calculation

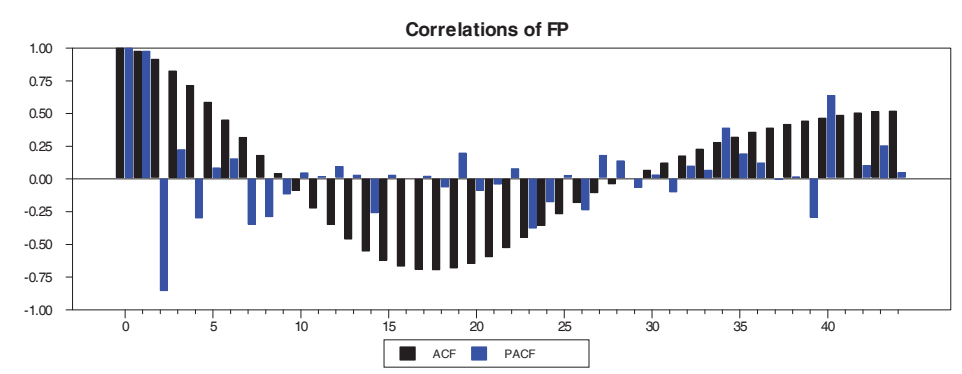

14a: Correlation of FP-milk

Source: author's calculation

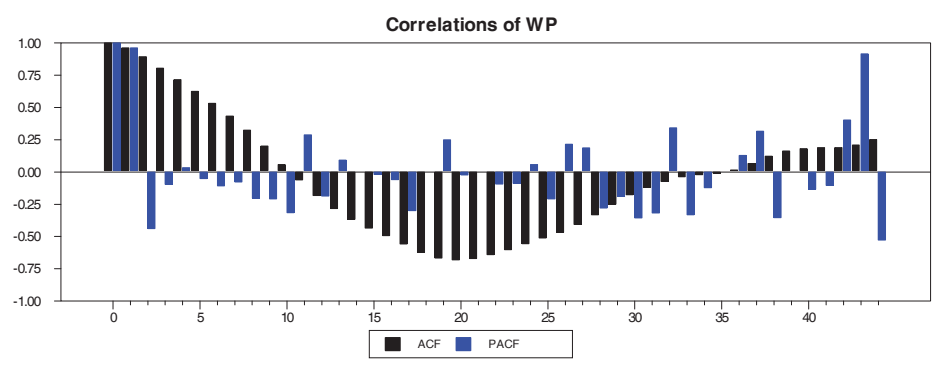

14b: Correlation of WP-milk

Source: author's calculation

to 2009. The price of milk then increases from this period until the current period. This development could be connected with the financial crisis and its consequences.

The main properties of the analyzed time series could be accompanied by an examination of a seasonal component. When the ACF and PACF functions are employed, there are no doubts about the presence of a seasonal component in the time series of the farm-gate price, as well as the time series of the wholesale price, of milk (see Figs. 14a, 14b).

After an examination of the main properties, the maximal lag was detected. The AIC and SBC criteria were employed for that purpose. Both tests suggested 11 lags as significant for the farmgate price and 18 lags for the wholesale price of milk. This would mean that the price of milk is set according to the values in the previous year, or year and a half, respectively. Given the time series length and the author's assumption, just three lags were selected as significant in the analyzed relationship and included in the following model.

Next, the properties of the time series important for the VAR or VECM model should be examined. First of all, the ADF test was employed to verify the assumption that the farm-gate price of milk as well as wholesale price of milk is non-stationary. The ADF test proves that the selected time series are non-stationary and integrated of order 1, i.e. I(1).

Co-integrating analysis was then employed to verify the long-term relationship between the farmgate price and wholesale price of milk. The cointegrated analysis confirmed the presence of one co-integrating vector at a significance level of $1 \%$; thus, the VECM model can be employed to describe price transmission in the analyzed agri-food chain. 
Table IV contains the parameters of the estimated VECM model and their t-values. The values included in the vector $\beta$ stand for price transmission elasticity. The value 1.043 means that the milk agri-food chain is characterized by imperfect competition, or more precisely, this agri-food chain can be considered oligopolistic, or both oligopolistic and oligopsonic. Moreover, the t-values of vector $\alpha$ confirm the assumption that the relationship between the farm-gate price and wholesale price of

IV: VECM model in milk agri-food chain

\begin{tabular}{ccccc}
\hline \multicolumn{2}{c}{ Beta (transposed) } & \multicolumn{2}{c}{ Alpha } & \multicolumn{2}{c}{$\begin{array}{c}\text { T-values } \\
\text { for Alpha }\end{array}$} \\
\hline $\log \mathrm{FP}$ & $\log \mathrm{WP}$ & $\log \mathrm{FP}$ & -0.202 & -5.940 \\
1.000 & -1.043 & $\log \mathrm{WP}$ & 0.433 & 2.845 \\
\hline \multirow{2}{*}{ PI } & & & \multicolumn{2}{c}{ T-values for PI } \\
\cline { 4 - 6 } & & & \multicolumn{1}{l}{$\operatorname{logFP}$} & $\operatorname{logWP}$ \\
\hline $\operatorname{logFP}$ & -0.202 & 0.211 & -5.940 & 5.940 \\
$\log \mathrm{W}$ & 0.433 & -0.452 & 2.845 & -2.845 \\
\hline
\end{tabular}

Sample: 45; effective sample: 38 ; degrees of freedom: 31 Source: author's calculation milk is simultaneous. The same result is provided by the test of exclusion.

Residual analysis provided satisfactory results (see Fig. 15). The model does not contain autocorrelation of residuals, so their distribution can be considered normal; in addition, there are no major differences between the real and fitted values. Moreover, the specification of the model can be considered appropriate.

\section{DISCUSSION}

Based on an empirical analysis of price transmission in the selected livestock agri-food chains in the Czech Republic, results concerning verification of the hypothesis were provided as follows:

H1: The time series of farm-gate prices and wholesale prices in the selected agri-food chains are non-stationary.

ACCEPTED

The ADF test was employed to detect the stationary or non-stationary character of the analyzed time series. The first hypothesis was accepted for all time series of farm-gate price as well as wholesale price. All these time series are therefore

\section{DLFP}
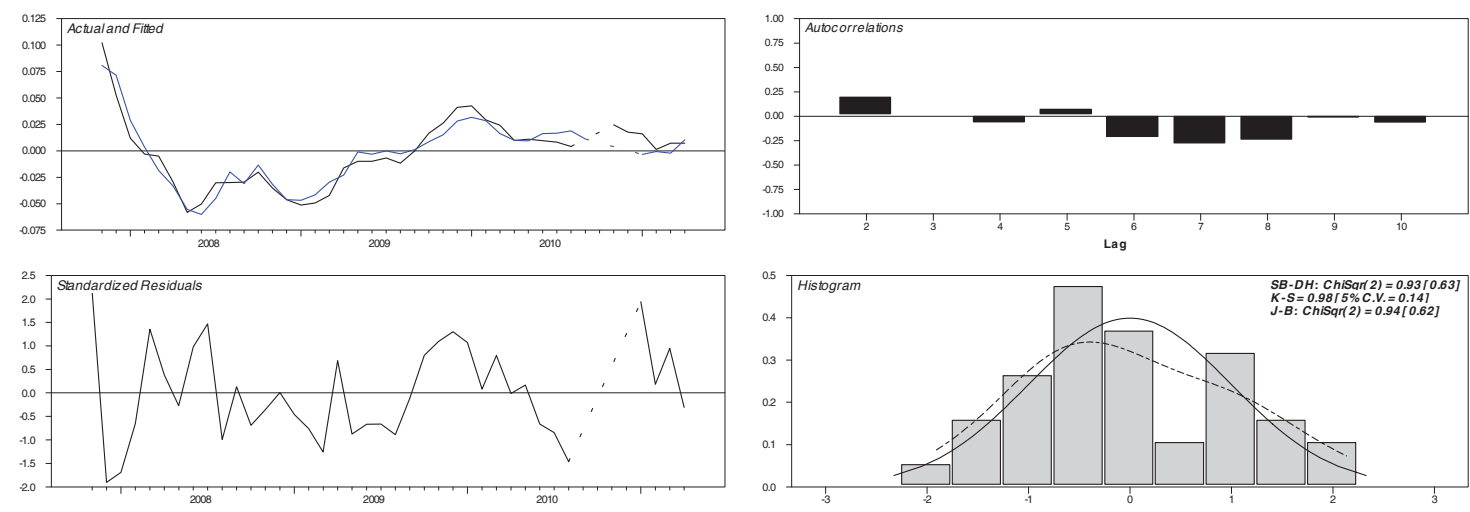

DLWP
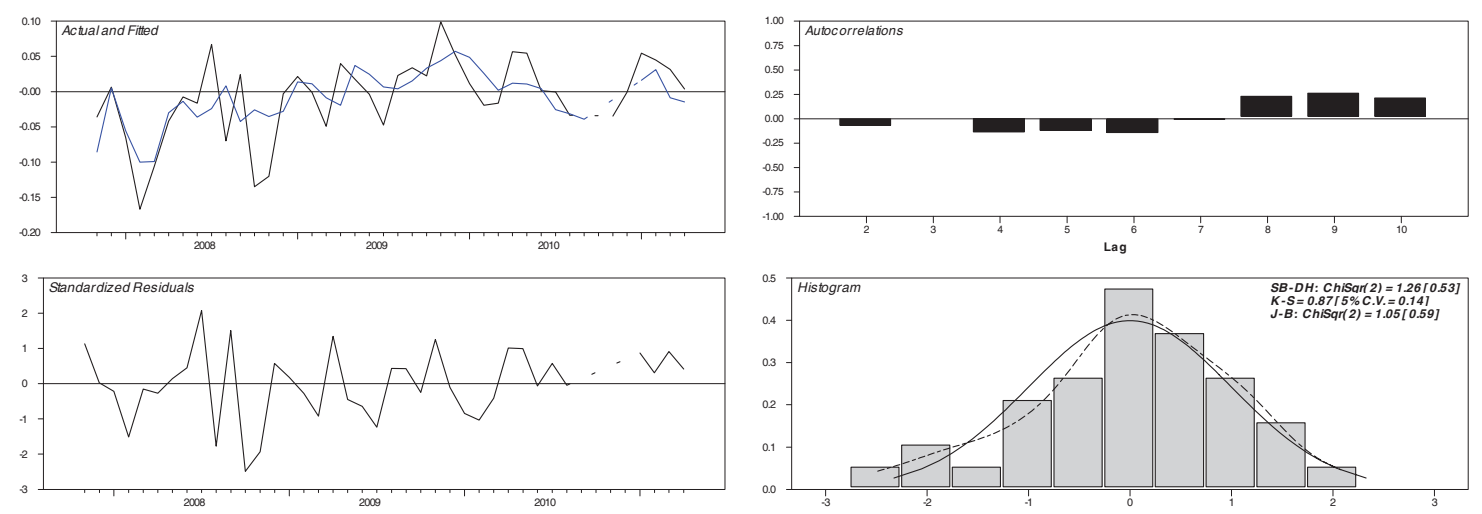

15: Residual analysis of milk VECM

Source: author's calculation 
non-stationary, which means that they contain a unit root. Moreover, all of these time series are integrated of the first order. In this case, the VECM model can be employed as a suitable tool for examining price transmission, in cases where co-integration analysis proves the existence of a long-term relationship between farm-gate price and wholesale price in individual agri-food chains. If it cannot be shown that there is a long-term relationship, then the VAR model is suitable.

H2: It can be assumed that there is a long-term relationship between farm-gate price and wholesale price in the selected agri-food chains.

REJECTED

Co-integration analysis was employed to detect whether a long-term relationship does indeed exist between farm-gate price and wholesale price in the selected agri-food chains. Co-integration analysis provided different results for the analyzed agrifood chains. Thus, the second hypothesis was not accepted as a whole. According to the results of the empirical analysis, a long-term relationship between farm-gate price and wholesale price in the pork, beef and milk agri-food chains might be considered, whereas the relationship in the poultry agri-food chain seems to be only short-term. It can be assumed that the poultry market is more sensitive to overall changes, and also that under current conditions, the generally assumed long-term contracts have expired and new contracts are being set up ad hoc. The tendency to move from long-term to short-term relationships is probably attributable to the economic crisis.

H3: It can be assumed that all the analyzed agri-food chains are demand-driven, which means that wholesalers have a stronger position than farmers.

REJECTED

To detect the nature of the market structure in the analyzed agri-food chains, the coefficient of price transmission elasticity was quantified. The third hypothesis was based on the general position of farmers in the Czech Republic as well as their relationships with processors and markets. According to the results of empirical analysis, the hypothesis was not accepted as a whole. All of the analyzed markets are characterized by imperfect competition; however, the nature of this competition changes from agri-food chain to agrifood chain. The estimated VECM models show that the market structure in pork and beef can be considered oligopsonic, while the market structure in the milk agri-food chain is either oligopolistic, or both oligopolistic and oligopsonic. The differences between the meat and milk chains could be attributable to the specifics of the milk market in the Czech Republic, especially after EU accession. The nature of the market structure of the poultry agrifood chain was not detected in more detail; in any case, imperfect competition may be considered as well.

The results for the pork agri-food chain slightly differ from the results obtained based on previous research in pork price transmission analysis (e.g., Čechura, Šobrová, 2008). The values of price transmission elasticity are in both cases lower than 1, which indicates an oligopsonic market structure. However, the absolute value of price transmission elasticity differs slightly (0.820 compared to 0.668 ). This result could be due to the fact that the price transmission analysis in this case was based on the times series of pork leg without bones (not, e.g., weighted wholesale price). Moreover, the data set was aggregated on the level of the Czech Republic; price transmission was not examined in individual regions. Thus, the results may differ from regional results. The economic situation of the Czech Republic, as well as in other countries, might provide another explanation for this result (different results compared to previous research). The previous research was based on the period up to the year 2007, the period before the economic crisis. Generally speaking, the economic crisis has probably influenced every country around the world, as well as every sector of their national economy. In light of this, it can be concluded that this situation has probably influenced the relationships in the meat (livestock) agri-food chains in the Czech Republic as well.

\section{CONCLUSIONS}

This paper deals with a description of selected livestock agri-food chains in the Czech Republic and an analysis of their price transmission. For these purposes, the agri-food chains of pork, beef, poultry and milk were selected as the main livestock chains in the Czech Republic.

Own analysis consists of two parts. First of all, the descriptive analysis is processed. This analysis is based on the time series of monthly data, provided by the Czech Statistical Office, on production, supply and consumption for the period from 1998 to 2009. These factors are important for setting up the price, and are therefore included in the paper. The second part of the analysis is focused on vertical price transmission in selected agri-food chains. This analysis is based on the biweekly or monthly time series of farm-gate price and wholesale price of the selected commodities in different periods, generally from May 2004 to June 2011, provided by the Ministry of Agriculture and the State Agricultural and Interventional Fund.

The price transmission analysis was focused especially on the long-term relationship between farm-gate price and wholesale price in individual agri-food markets. Co-integration analysis proved the existence of a long-term relationship in all agrifood chains except for the poultry market. Then, the VECM model showed imperfect competition in the form of oligopsony or oligopoly. In almost all cases, it can be assumed that wholesalers have a stronger position than farmers. Thus, most of the analyzed agri-food chains can be considered demand-driven. 


\section{SUMMARY}

The paper deals with quantitative analysis of selected agri-food chains. The aim of this paper is to examine the market structure of selected livestock agri-food chains in the Czech Republic, and more specifically to describe the main factors in the selected livestock agri-food chains and evaluate their price transmission based on the time series of farm-gate price and wholesale price. The paper is focused on the pork, beef, poultry and milk sectors. The analysis is separated into two parts. First of all, a description of the selected agri-food chains is provided. The development of the main factors, namely the production, supply and domestic consumption of selected livestock products, is examined and described based on the time series of monthly data for the period 1998-2009. Subsequently, the market structure of the selected agri-food chains is examined based on vertical price transmission analysis. Price transmission in the pork and beef agri-food chains is based on the time series of farm-gate price and wholesale price bi-weekly data for the period from May 2004 to April 2011, and price transmission in the poultry and milk sectors is based on the time series of farmgate price and wholesale price monthly data for the period from July 2007 to May 2011. To analyze the market structure, the Vector Autoregressive Model, Vector Error Correction Model and co-integration analysis are employed. The data set was provided by Ministry of Agriculture and State Agricultural Interventional Fund. The calculations were done with the help of the econometric software RATS and CATS. The analysis shows the long-term tendencies of selected market factors in the analyzed period for all analyzed markets. A long-term relationship between farm-gate price and wholesale price is then detected for all examined agri-food chains except the poultry chain. Finally, the analysis shows that the analyzed agri-food chains can be considered markets with imperfect competition, in the form of either oligopsony or oligopoly. The nature of the market structure shows some differences among the analyzed agri-food chains. In almost all cases, it can be assumed that wholesalers have a stronger position than farmers. Thus, most of the analyzed agri-food chains can be considered demand-driven.

\section{Acknowledgement}

The results presented in this paper are outputs of the research project "P402/11/P591 Modelling of price transmission and its asymmetry in agri-food chain - theoretical-empirical implications" supported by Czech Science Foundation.

\section{REFERENCES}

BAKUCS, L. Z., FERTÖ, I., 2005: Marketing margins and price transmission on the Hungarian pork meat market. Agribusiness, Vol. 21, Issue 2. ISSN 15206297.

BOJNEC, S., 2002: Price transmission and market margins in the Slovenian beef and pork markets during transition. $\mathrm{X}^{\text {th }}$ EAAE Congress.

ČECHURA, L., ŠOBROVÁ, L., 2008: The price transmission in pork meat agri-food chain. Agric. Econ. - Czech, 54, 2008 (2). ISSN 0139-570X.

ČECHURA, L., ŠOBROVÁ, L., 2009: The Nature of Price Transmission in the Pork Agri-food Chain. Scientia Agriculturae Bohemica, Vol. 40, No 3-2009. ISSN 1211-3174.

ČECHURA, L. a kol., 2010: Produkční funkce v živočisné výrobě. Key Publishing, Ostrava. ISBN 978-807418-090-3.

CHADDAD, F., RODRIGUES-ALCALÁ, M. E., 2010: Inter-organizational relationships in agri-food systems: a transaction cost economics. In; Agri-food Chain Relationships. CABI, UK. ISBN 978-1-84593-6426.

HARTMANN, M. et al., 2010: Buildings sustainable relationships in agri-food chains: challenges from farm to retail. In: Agri-food Chain Relationships. CABI, UK. ISBN 978-1-84593-642-6.

JENSEN, J. D., MØLLER, A. S., 2007: Vertical price transmission in the Danish food marketing chain. ISBN 978-87-92087-21-8.
LEAT, P. et al., 2010: Trust and relationships in selected european agri-food chains. In: Agri-food Chain Relationships. CABI, UK. ISBN 978-1-84593-6426.

LECHANOVÁ, I., 2006: The transmission process of supply and demand shocks in Czech meat commodity chain. Agric. Econ. - Czech, 52, 2006 (9). ISSN 0139570X.

LLOYD, T. et al., 2004: Price transmission in imperfectly competitive vertical markets. Discussion Papers in Economics No. 04/09, University of Nottingham.

MACH, J. et al., 2010: Modelling the cattle breeding production in the Czech Republic. Agris on-line Papers in Economics and Informatics, Vol. II, No. 3/2010. ISSN 1804-1930.

MAIER, T., PÁNKOVÁ, L., 2010: Sectoral production function of chicken broiler fattening. Agris on-line Papers in Economics and Informatics, Vol. II, No. 4/2010. ISSN 1804-1930.

MALY, M., 2009: Price models in poultry meat vertical. Scientia Agriculturae Bohemica, Vol. 40, Issue 2009 (2). ISSN 1211-3174.

MALY, M. et al., 2011: Potential for pork production in the Czech Republic. Agric. Econ. - Czech, 57, 2011 (11). ISSN 0139-570X.

MIELE, M., 1999: Short circuits: new trends in the consumption of food and the changing status of meat. International Planning Studies, October 1999, Vol. 4, Issue 3. ISSN 1356-3475. 
PALÁT, M. et al., 2012: Consumption of beef in the Czech Republic. Agric. Econ. - Czech, 58, 2012 (7). ISSN 0139-570X.

ŠOBROVÁ L. et al. 2011: Partial equilibrium model case study of the poultry market. Acta Universitatis Agricuturae et Silviculturae Mendeleianae Brunensis. Vol. LIX, No. 7/2011. ISSN 1211-8516.

VAVRA, P., GOODWIN, B. K., 2005: Analysis of price transmission along the food chain. OECD France,
Agriculture and Fisheries Working Papers, No. 3, OECD Publishing; doi: 10.1787/752335872456.

Statistical Yearbook of the Czech Republic 2011. Czech Statistical Office, Prague 2011.

Ministry of Agriculture: http://www.mze.cz

State Agricultural Interventional Fund: http://www. szif.cz

Address

Ing. Lenka Rumánková, Ph.D., Katedra ekonomiky, Provozně ekonomická fakulta, Česká zemědělská univerzita v Praze, Kamýcká 129, 16521 Praha 6 - Suchdol, Česká republika, e-mail: rumankova@pef.czu.cz 